\title{
Profilaxia do tifo exantemático neotrópico no Brasil (*)
}

\author{
por \\ Octavio de Magalhães
}

A profilaxia racional de uma doença decorre do melhor e mais profundo conhecimento dela. A do Tifo exantemático neotrópico, apesar do que se sabe da doença, não é fácil no Brasil. Uma das primeiras dificuldades está na real incultura da maioria dos homens de campo entre nós. Ora, é no campo principalmente ou nas zonas da cidade que confinam com o campo, que a doença dizima os indivíduos. São quase sempre "pobres diabos", mas é impressionante não raro a robustez de muitos dêles, que vivem em tôrno das grandes cidades, onde a higiene já penetrou, com alguns de seus postulados. Mas é justamente porque a doença tem atacado pessoas de pouca influência social, que o problema ainda não foi resolvido entre nós.

O homem se infecta certamente com as raças VB, VA 1 e VA 2 do vírus brasileiro :

$10^{\circ}$ - no campo, nas matas e nas macegas;

2. ${ }^{\circ}$ — dentro dos domicílios ou nos arredores dêstes.

Os primeiros constituem de regra os casos insulados do mal; os segundos fazem parte não raro dos fócos domiciliares macissos, com dois, cinco, sete e até doze casos na mesma casa.

São responsaveis pelos primeiros os carrapatos, principalmente o Ambiyomma cayennense e o Amblyomma brasiliense, especialmente no período de ninfas, dada a herança habitual da infecção nêsses artrópodios, que se infestam nos animais silvestres, depositários de virus, cujo nome e número já temos descrito em numerosos trabalhos.

São responsaveis pelos segundos o Cimex lectularius principalmente e as ninfas e larvas de carrapatos deixados cair nas proximidades dos domicílios.

Os percevejos e mesmo as larvas dos carrapatos, nas vizinhanças das casas, podem se infestar no homem (que também pode ser depositário de

(*) Trabalho do Instituto Oswaldo Cruz. Divisão de Estudos de Endemias. Laboratório de Fisiologia da Faculdade de Medicina da U.M.G. - XII-1948. 
virus), nos cães, já agora nos cabritos também, que têm de regra a doença inaparente, com o virus no sangue, por algum tempo. Êstes animais domésticos, todos sabem, são comensais do homem no interior do Brasil, dormindo não raro, alguns, junto ao homem, no mesmo leito ou debaixo dêste. Por isto, a profilaxia racional e completa da doença entre nós compreenderia as seguintes medidas:

\section{1. ${ }^{\mathrm{a}}$ - Descatrapatização das zonas infestadias.}

A primeira vista êste conselho póde ser um contrasenso. Sentimos isto quando, conversando um dia com um alto funcionário administrativo do Brasil, percebemos que êle não podia conter o riso e por fim a gargalhada, lhe aconselhamos a possibilidade de exterminar os carrapatos, não só em certas zonas do Estado de Minas, como de outra, de qualquer Estado do Brasil. Citámos o exemplo dos Estados Unidos da América do Norte, no combate à Febre do Texas ou Piraplasmose bovina. Aliás, se alguem falasse em exterminar os mosquitos no Rio de Janeiro, ou melhor, a determinada espécie de mosquitos do Rio de Janeiro, antes da éra Oswaldina, seria, como êle foi no começo, rotulado de impostor ou louco. No entanto, a campanha de Oswaido Cruz foi um triunfo para a ciência brasileira. A matança do Anopheles gamoial, no Nordeste brasileiro, é um padrão de trabalho nêsse gênero e salvou milhares de nossos patrícios da morte pela malaria.

Os banheiros carrapaticidas seriam multiplicados, principalmente em tôrno das grandes cidades onde a moléstia foi localizada: Belo Horizonte, Sabará, Teófilo Otoni, Pitanguí, Araxá, Pomba, Aiuruóca, São Paulo, etc. Um dia talvez fosse possível generalizando essa medida, tornar cada vez mais pobres em carrapatos os campos de Minas Gerais, São Paulo e Rio de Janeiro. Os benefícios que a descarrapatização traria aos rebanhos e ao homem seriam enormes. Já é um assunto estudado e pacífico em veterinária o que representa a sangria e conseqüente anemia dos bovideos que vivem $\mathrm{em}$ campos com carrapatos. Já não falamos das doenças que os Ixodidae acarretam aos bovídeos e aos equídeos que, sem ter coisa alguma, mantém carrapatos infectados pelos virus VB, VA 1 e VA 2 do Tipo exantemático neotrópico, deixando cair êstes artrópodo's próximo aos domicílios, nos pátios, veredas e campos.

Em 1935-1936, nós pugnámos em Minas Gerais para que se fizesse, em tôrno de Belo Horizonte pelo menos, um ensaio neste sentido. O projeto de lei n. ${ }^{\circ}$ 27, de 21 10 1936, do Conselho Municipal de Belo Horizonte, inspirado por nós, visava, se bem que ainda muito timidamente, justamente êste 
assunto. Era nosso pensamento obter coisa mais positiva e enérgica. Mas antes ter alguma coisa do que continuar desarmado neste terreno.

\section{Dizia o projeto:}

Art. 1. ${ }^{\circ}$ - Fica proibida a formação de pastos, bem assim a sua exploração, sob qualquer forma, nas zonas urbana e suburbana, bem como nas vilas da capital.

$\S 10^{\circ}$ - O Prefeito poderá, entretanto, autorizar a formação de pastos na zona subur bana, depois de ouvida a Diretoria de Saúde Pública.

§ 2." - Na zona suburbana e nas vilas, o Prefeito poderá autorizar a plantação de capinzais para córte, a requerimento dos interessados, depois de ouvida a Diretoria de Saúd? Pública.

Art. 2. ${ }^{\circ}$ - Os proprietários ou arrendatários dos terrenos incultos situados nessa zona são obrigados a conservá-los limpos, roçando ou queimando o matagal nêles existente, conservando as matas cercadas, se por acaso existirem.

Art. $3 .^{\circ}-$ Os proprietários ou arrendatários dos terrenos incultos ou cobertos de capinzais serão intimados, no prazo de 30 dias, a cumprir as exigências do art. anterior.

Art. $4 .^{\circ}$ - Aos infratores da presente lei serão aplicadas as multas de $200 \$ 000$ (duzentos mil réis), para os terrenos situados na zona urbana e $100 \$ 000$ (cem mil réis), para as zonas suburbanas e para as vilas, cobradas em casns de reincidencia.

Art. 5. - Fica o Prefeito autorizado a concorrer com o auxilio de 1:000\$000 (um conto de réis) a todo aquêla que construir um banheiro carrapaticida, na sua propriedade, dêscle que esta seja indicada pela Saúde Pública.

Art. $60^{\circ}$ - Fica o Prefeito autorizado a abrir o crédito até o máximo de 20:000\$000 (vinte contos de réis) .

Art. 7. - Esta lei entrará em vigor no próximo ano de 1937.

Art. $8 .^{\circ}-$ Revogam-se as disposições em contrário (*).

Como vemos, não é um projeto decisivo, se bem que contenha medidas de profilaxia racionais da doença, em tôrno da capital mineira. Mas mesmo esta lei não foi cumprida. Para que ela desse resultados, e em nove anos já teria sido possivel vêr algum, seria necessário tornar os banhos obrigatorios para todo animal, na zona suburbana e rural de Belo Horizonte, sem excep ção de espécie alguma, qualquer que fosse o proprietário e a sua posição social.

Em tôrno da capital de São Paulo, feita pelo município, há também uma lei neste sentido e o trabalho do dr. Amâncio Cândido Esquibel é expressivo, sôbre os resultados da aplicação dela.

$\left({ }^{\star}\right)$ Álvaro Camargos. Apresentação: 21-1-1936 (16, ${ }^{a}$ seção). Emendas: 12-11-1936 (30. ${ }^{\mathrm{a}}$ Sessão) . 


\section{Eis o teôr do Decreto :}

Art. $10^{\circ}$ - Fica a Diretoria de Industria Animal, da secretária da Agricultura, Indústria e Comércio, autorizada a delimitar a zona de combate aos parasitos transmissores do Tifo exantemático.

§ único - Esta zona abrange inicialmente o município de São Paulo e outros circunvizinhos.

Art. 2. ${ }^{\circ}$ - Da zona delimitada não poderá sair, sen autorização da Diretoria de Indústria Animal, nenhum animal bovino, equino, azinino, nuar, caprino, ovino, canino e outros portadores do parasito.

Art. $3 .^{\circ}$ - Para o serviço de exterminio dos parasitos a Diretoria de Indústria Animal fará construir banheiros carrapaticidas, localizados nos pontos mais adequados.

$\S$ único - Os matadouros e frigorificos ou outros estabelecimentos que possuam grande número de animais, deverão construir, dentro de 30 dias, os banheiros carrapaticidas necessários, obedecendo para isso ao prejeto fornecido pela Diretoria de Indústria Animal.

Art. $4 .^{\circ}$ - Os proprietários de animais enumerados no art. $2 .^{\circ}$, ficam obrigados a passá-los nos banheiros carrapaticidas de 20 em 20 dias, a juizo dos fiscais da Diretoria de Indústria Animal.

Art. $5 .^{\circ}$ - Nos banheiros carrapaticidas particulares serão observadas as mesmas normas de trabalho instituidas para os banheiros oficiais.

Art. $6 .^{\circ}$ - E' vedado às estradas de ferro, ou às empresas de transporte conduzir para fora da zona interditada qualquer dos animais enumerados no art. $2 .^{\circ}$, sem a necessária guia de trânsito, passada pela Diretoria de Indústria Animal e sem que o veículo que os tiver de transportar, ter sido desinfectado rigorcsamente.

Art. $70^{\circ}$ - As estradas de ferro que receberem animais do interior para a zona interditada, poderão aceitá-los a despacho, para a estações indicadas pela Diretoria de Indústria Animal (da mesma Diretoria).

Art. 8. - Não é permitida, sob pena de apreensão, a permanência livre de animais em terrenos baldios, dentro da zona infectada.

Art. 9. - O rebanho bovine existente na zona interditada, ficará sob a vigilància rigorosa da Diretoria de Indústria Animal.

Art. 10. ${ }^{\circ}$ - A Diretoria de Indủstria Animal e a Diretoria Geral do Serviço Sanitário, por intermédio dos seus funcionárics, destruirão os cães vadios e os roedores, encontrados nas zonas interditadas e suas proximidades.

Art. $11 .^{\circ}$ - Os animais que forem enviados para fóra da zona interditada, serão fichados pela Diretoria de Indústria Animal, que mencionará também o seu destino c remeterá a ficha, para os devidos fins, ao Serviço Sanitário.

Art. $12 .^{\circ}$ - As autoridades policiais prestarăo aos funcionários da Diretoria de Industria Animal e do Serviço Sanitário, encarregados da execução dêste Decrato, o auxílio que por êles lhes fôr solicitado.

Art. $130^{\circ}$ - As despesas com a execução dêste Decreto, até o limite de 100 contos, correrão por conta do $\S 4 .^{\circ}$, do Art. $7 .^{\circ}$, do Dec. n. ${ }^{\circ} 6$ 261, de 30 de dezembro de 1933. 
2. ${ }^{a}$ - Combate aos cães vadios, cabritos e outros animais portadores do vitus,

Èm artigos anteriormente publicados já dissemos quais os principais portadores do virus do Tifo exantemático neotrópico no Brasil.

O combate deve visar, em primeiro lugar, o cão doméstico (Canis familiaris). Matar os desnecessários e vacinar anualmente, com um tipo de vacina mista das raças do virus brasileiro do Tifo exantemático neotrópico, os demais cães de serviço e de luxo, que ficarem nos domicílios. O mesmo diriamos para os gatos (Felix domesica) e para os cabritos (Capra hircus). Os demais animais devem ser caçados ou eliminados por tóxicos, de modo a afastá-los completamente da vizinhança das casas e mesmo dos pastos e macegas mais próximos dos domicílios. Não é difícil a caçada aos gambás, raposas, cotias, gatos do mato, etc.

3. ${ }^{a}$ - Os pastos, campos e macegas de fraco valor econômico devem ser queimados anualmente, principalmente os que confinam com os arrabaldes das cidades, onde há muitas casas residenciais. A queimada na época das sêcas, tempo frio, distruirá uma certa percentagem de carrapatos em estado larvário ou de ninfas.

Além de fastar os pequenos animais portadores do virus, estas queimadias impedem, naturalmente, que bovídeos e equídeos, portadores de carrapatos, busquem as vizinhanças das residências, para a alimentação e aí deixem cair os artrópodos infectados.

Naturalmente estas queimadas devem ser: orientadas e feitas dentro de zonas determinadas e que não prejudiquem as culturas.

$4 .^{a}$-- Fazer uma propaganda de fato contra a doença exantemática neotrópica, entre a população urbana e rural das zonas infestadas :

a) palestras locais com fotografias e gráficos;

b) pelo cinema, com filmes apropriados:

c) por pequenos artigos de jornais de grande circulação;

d) em folhetos apropriados, escritos em linguagem simples, com fotografias de doentes graves e a percentagem de mortes dêstes casos;

e) mostrar o papel dos cães, gatos, cabritos e animais silvestres, do percevejo e do carrapato, na disseminação da doença.

$5 .^{a}$ - Combater toda a vermina dentro dos lares e nos arredores dos domicílios.

$6{ }^{a}$ - Mostrar que é possivel evitar, com toda a certeza, a infecção pelos carrapatos, desde que se retirem êstes dentro de 12 ou 14 horas após a fixação no corpo do paciente. 
Basta para isto que, após a volta dos campos, seja possivel esta cata racional nos indivíduos, dos carrapatos fixados, por vários processos, mesmo câseiros.

7." - Acoriselhar o emprego do DDT, "Gammexane" e "Toxafeno" para o expurgo das casas dos animais e impedir mesmo que os carrapatos se fixem no homiem ou nos animais, pelo emprego daquêles poderosos inseticidas.

8. ${ }^{a}$ - Vacinação preventiva contra a doença, principalmente dos indiví duos que, pela profissão nos fócos conhecidos do mal, tenham que se súbmeter a reinteradas e numerosas picadas de carrapatos e percevejos. A vacina deve ser feita com várias amostras do virus VB do Brasil. O ideal seria cada Estado, em cujo território já houvesse sido encontrada a doença, fundar um instituto ou um secção do inst:tuto destinado ao fabrico da vacina. Êste, aliás, era o nosso plano, quando organizámos o Instituto Biológico Ezequiel Dias em Minas Gerais. Seria talvez conveniente que uma comisão de técnicos brasileiros estudasse o problema e patronizasse a técnica de preparo da vacina no país.

Quem quizer ter uma idéia da quantidade e variedade de tipos de vacina hoje empregados, basta lêr as publicações de Clavero del Campo e Peres Galliardo, de 1941 e 1943 e de L. Albaladejo, 1941.

Os tipos de vacina são numerosos e ainda há outras variantes, feitas em outros animais, com outras drogas, mas no fundo com os mesmos princípios de técnica.

A vacina tipo Spencer-Parker, com a qual trabalhámos durante algum tempo, é realmente um bom produto e tem no seu activo mais de 15 anos de emprego, nos Estados Unidos. Era êsse tipo de vacina que pretendiamos fazer, no novo pavilhão do Instituto Biológico Ezequial Dias, na Gameleira, antes de conhecermos o tipo da vacina e a técnica de Cox mais simples, menos perigosa e parece que não menos eficiente. Chegámos mesmo a ter con o grande técnico norte-americano R. R. Parker uma larga correspondência, sobre a organização do serviçc no Instituto de Hamilton, Montana, U. S. e da técnica de preparo em larga escala do produto. Êle me mandou fotografias, desenhos, planos, descrição pormenorizada da técnica, etc., pondo-me assim ao par de como se trabalhava naquele grande Instituto norte americano.

O preparo da vacina Spencer-Parker é delicado, pede instalações especiais, técnica meticulosa e segura contra os perigos, a que se expõem os que nela trabalham, uma grande aparelhagem para criação em grande escala do 
carrapato. Naturalmente depois que a gente se entrega a êstes trabalhos, tudo parece simples e em Montana realmente as cousas devem ser magníficas, para produção em alta escala da vacina. Mas não o fôram assim no início dos tra balhos, conforme relata Parker. Quem trabalha com o grupo Tifo exantemático, sabe que o perigo das manipulações estâ primeiro no hábito de lidar com material altamente virulento, que leva os auxiliares, no fim de algum tempo, a certos descuidos fatais, que não poucas vidas têm ceifado. Pensamos mesmo que nenhuma outra moléstia tem morto tantos pesquisadores que com ela têm lidado.

O segundo perigo está no trato com os artrópodos transmissores. O virus, por si próprio, os doentes, os animais infectados, os cadáveres dêstes e dos homens representam perigos relativamente fáceis de afastar. Os artrópodos, não. São, de fato, pelo tamanho e número e certamente pela exaltação da virulência do micróbio, um perigo real, permanente, de difícil afastamento. Quase todos os casos, e já são numerosos, de infecção nos laboratórios pelo virus das doenças do grupo Tifo exantemático, foram consequências de manipılações pouco cuidadosas com artrópodos infestados. E' preciso ter, além de uma técnica segura, uma vigilância permanente de tudo e todos, para que não se dêm acidentes dolorosos em laboratórios comuns de pesquisas, onde se lidam com êstes vectôres. Por isto, si tivessemos de em pregar, no estado atual de nossos conhecimentos no Brasil, um tipo de vacina, dado o que já se afirma, preferiamos o tipo Cox, produto de relativa simplicidade, no preparo e contrôle. Queremos, todavia, assinalar ưn ponto de capital importância, para a vacinação preventiva contra o Tifo exantemático neotrópico no Brasil. E' a experiência longa na prática dos problemas epidemiológicos dêste grupo de doenças, que nos dita o cuidado que devemos têr, antes de conclusões rijas, sôbre o resultado do emprego do produto. A primeira cousa a que nos devemos ater, é a questão das dóses e da reacção que a vacina provoca. Uma cousa é vacinar empregados de uma companhia particular, soldados ou funcionários técnicos de um Instituto ou de uma repartição oficial. Cousa muito diferente é vacinar um grupo de indivíduos incultos, cépticos quanto à medicina e aos médicos, que devem tomar um produto, uma injecção, para evitar a doença. E' necessário ainda não esquecer que, quando a vacina dá reacção, dificilmente os "caipiras" voltam a tomar segunda. Tivemos fatos semelhantes, até com vacinações contra a Raiva, no Instituto Biológico Ezequiel Dias e vimos morrer com a hidrofobia uma criança, cujo pai suspendera o tratamento na segunda dóse da vacina, porque esta dera ligeira reacção local. E' preciso também lembrar que as formas graves do Tifo exantemático neotrópico não têm numa localidade a abundância da variola 
ou da febre amarela silvestre, em época de epidemia. Os "caipiras" costumam afirmar que "não paga a pena" ser espetado por uma doença que mata ćois ou três indivíduos, num pequeno arraial.

Fora das épocas de epidemias, num meio inculto como o do interior do país, qualquer injecção preventiva seria em vão tentada. Injectar preventivamente num indivíduo, no nosso sertão, uma dóse de vacina é difícil. Injectar đuas ou três dóses só com muito trabalho. Não esquecer principalmente as distâncias de comunicações do interior do Brasil, com as injecções intercaladas, como acontece, por exemplo, com as vacinas tipo Spencer Parker, que, além de tudo, dão reacções, não raro violentas. O ideal seria a vacinação com uma dóse só de vacina preparada com várias amostras de virus brasileiro, pela técnica de Cox.

O outro ponto, para o qual a nossa experiência manda ser precavido, é na conclusão da profilaxia que efetivamente o produto tenha feito da moléstia. O silêncio dos fócos, durante vários anos, em casos graves do Tifo exantemático neotrópico, sem que se tenha tomado para isso qualquer medida profiláctica geral ou individual, já apurámos várias vezes em Minas Gerais. Vou dar um exemplo irretorquivel e expressivo do que afirmamos.

O arraial de Gorduras é um dos grandes fócos do Tifo exantemático neotrópico em tôrno de Belo Horizonte. E' local de fácil acesso e nêle pudemos fazer, pelo número relativamente pequeno de habitantes, uma fiscalização rigorosa. Em 1929, houve lá um pequeno número de casos graves. Em 1931, se registraram mais três casos graves. Dessa data até 1936, nenhum caso novo lá poude mais ser registrado, sem que nenhuma medida profiláctica, individual ou colectiva, tivesse sido tomada. Si houvessemos vacinado o pessoal daquêle arraial, afirmariamos com certeza e proclamariamos aos quatro ventos a eficácia de nossa vacina. Porque o fóco silenciou, a princípio, dois e depois cinco anos? Hoje podemos responder que êle silenciou apenas para as formas graves, mas certamente continuaram abundantes as formas benígnas e inaparentes da doença, que garantem também o silêncio aparente dos fócos. Estas formas são mantidas pelos percevejos ("Cimex lectularius") e mesmo pelos carrapatos, inoculadores de raças VA 1, VA 2 e mesmo VB, em indivíduos já velhos moradores no local. E' esta imunidade que explica o silêncio espontâneo dos fócos. Um dia a resistência adquirida pelos pacientes é vencida, ou pela inoculação acidental de uma maior quantidade da raça VB ou pela quéda da imunidade adquirida, por motivos vários e as fórmas graves reaparecem agora, em alguns poucos casos e não raro em um único caso, em toda uma localidade e onde todos estão sujeitos às mesmas picadas dos hema- 
tófagos, vectores do virus e onde a vida é mais ou menos a mesma para todo o mundo. Os casos graves, esporádicos, nestes fócos, pódem ser também a conseqüência de moradores novos, recemchegados de zonas idemnes do doença.

São estas extinções espontâneas e aparentes dos fócos que nos devem tornar muito exigentes e mesmo reservados, para as conclusões a respeito do êxito das vacinações em massa das populações do interior do Brasil, enquanto não tivermos uma maior e mais larga experiência sôbre o produto.

Há ainda um escolho a vencer. Se as vacinas preventivas do grupo exantemático dessem, como, por exemplo, a vacina da Febre amarela, uma imunidade duradoura, seria vantajoso imunizar toda uma população de uma zona flagelada. Mas na prática não é isto que acontece. Os técnicos dos Institutos que labutam com o material virulento, são sujeitos a revacinaşões todos os anos, para garantia da imunidade e mesmo no fim de dois, três e até cinco anos de revacinações pódem adquirir a moléstia, embora benígna.

Parker dizia, em 1935:

"The degree of this residual immunity appears to be greater in persons who have been vaccinated two or more successive years".

Em 1941, disse o seguinte :

"The degree of protection conferred varies with the individual, the relative virulence of the infecting strain, the number of successive years that vaccine has been administered, and perhaps to some extent with the age of the person vaccinated. The duration of any consequential degree of protection probably seldom exceeds the year of vaccination, except under certain circunstances and immunization each year is the only safe procedure".

No interior do Brasil isto seria difícil: nos laboratórios de pesquisa, não. E' necessário uma longa propaganda sanitária, preparatória aos trabalhos de imunização.

A imunização conferida pelas vacinas é precoce, mas não definitiva ou absoluta. Assim, aliás, deve ser, pois a resistência obtida com o próprio virus vivo nos fócos da doença, pelos antigos moradores, póde ser vencida, de uma feita, pela raça VB matando os pacientes.

Entre nós, a vacina Cox, de acôrdo com o padrão estabelecido pelo autor, vem sido produzida regularmente, com a eficiente ação antigênica pelo $\mathrm{dr}$. José Tostes, no Departamento de Saúde Pública do Estado do Rio de Janeiro, Niteroi, de acôrdo com a publicação na Revista de Biologia em 1944.

A vigilância nos fócos, para os recemchegados, e principalmente para os portadores humanos da doença benígna e inaparente como depositários de virus capazes de irradiar a doença é necessário. 
No trabalho de alto interesse, em 1945, publicado no Brasil Médico em complemento ao que já escrevera em 1942, o notável pesquizador paulista, Toledo Piza, aconselha mais:

1. ${ }^{\circ}$ - o amanho da terra, arando-a e plantando a;

2. ${ }^{\circ}$ - a derrubada das matas locais

$3^{\circ}$ - a drenagem das lagoas.

Tudo isto, é lógico, visando afastar os carrapatos. Se fosse possível eli minar o virus no exterior, nas zonas habitadas, a doença estaria debelada, porque é dalí que ela vem e penetra no interior das habitações constituindo os fócos domiciliares maciços.

\section{RUSUMO}

A profilaxia racional de um doença decorre do melhor e mais profundo conhecimento dela. A do tifo exantemático neotrópico, apesar do que se sabe da doença, não é fácil no Brasil. Uma das maiores dificuldade encontramos nas distancias do nosso "hinterland" e na falta de cultura dos nossos agricultores.

O homem se infecta certamente com as raças VB, VA e VA do virus brasileiro:

$\left.1 .^{\circ}\right)$ no campo, nas matas e nas macegas;

2. ${ }^{\circ}$ ) dentro dos domicílios ou nos arredores dêstes.

Os primeiros constitúem, de regra, os casos insulados do mal. Os segundos fazem parte, não raro, dos focos domiciliares maciços, com 2, 5, 7 e até 12 casos na mesma casa. São responsáveis, pelos primeiros, os carrapatos, principalmente o Amblyomma cayennense e o Amblyomma brasiliense, mormente quando no estado de ninfas, dada a herança habitual das infecçôes nesses artrópodos, que se infestam em animais silvestres, depositários do virus.

São responsáveis pelos segundos, os "Cimex lectularius", percevejos dos leitos e as ninfas e larvas dos carrapatos, deixadas cair junto aos domicílios ou mesmo dentro deles.

A profilaxia racional e completa da doença entre nós compreende:

$1^{\circ}$ ) Descarrapatização das zonas infestadas, por meio de leis apropriadas, coercitivas e aplicadas sem excepção; 
$\left.2 .^{\circ}\right)$ Combate aos cães vadios, cabritos e outros animais portadores do virus;

3. ${ }^{\circ}$ Queima dos pastos, campos e macegas de fraco valor econômico, principalmente os que confinam com residências;

4. ${ }^{\circ}$ A propaganda racional contra esta grave doença exantemática: a) com palestras locais, acompanhadas de fotografias e gráficos expressivos e ao alcance de todos; $b$ ) pelo cinema; c) com artigos simples, claros e precisos sôbre a matéria; $d$ ) com folhetos apropriados;

5. ${ }^{\circ}$ Combater toda a vermina dentro e nas proximidades dos domicílios,

$6^{\circ} .^{\prime}$ Demonstrar que é possível, com toda a certeza, evitar a doença, retirando os carrapatos que se prenderem ao corpo, dentro de 12 ou 14 horas após a fixação;

7. ') Aconselhar o emprêgo do DDT, "Gammexame" e "Toxafeno" para o expurgo das casas e animais, a fim de combater os carrapatos;

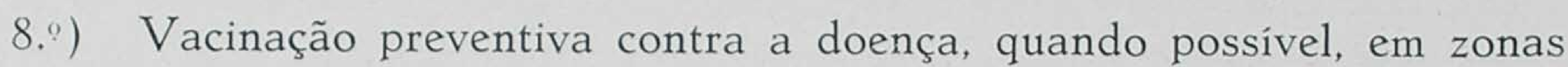
delimitadas e já civilizadas, feitas principalmente com raças de virus colhidas no Brasil e, se possível, com uma só dose. O autor trabalhou durante algum tempo com a vacina tipo Spencer Parker. Hoje aconselha o trabalho com a vacina tipo Cox, original ou modificada. 